\title{
Cash Conversion Cycle and Firm's Profitability: An Empirical Analysis on a Sample of 4,226 Manufacturing SMEs of Italy
}

\author{
Marco Muscettola ${ }^{1}$ \\ ${ }^{1}$ Credit Risk Manager and independent researcher, Italy \\ Correspondence: Marco Muscettola, Credit Risk Manager and independent researcher, Italy. E-mail: \\ marcomuscettola@hotmail.com
}

Received: January 28, 2014

Accepted: March 7, $2014 \quad$ Online Published: April 18, 2014

doi:10.5539/ijbm.v9n5p25

URL: http://dx.doi.org/10.5539/ijbm.v9n5p25

\begin{abstract}
The aim of this paper is to verify the impact and all the influences of the cash conversion cycle on the profitability of firms. Using data from an extensive sample of Italian manufacturing firms (4,226 Italian SMEs), the present study is concerned about evaluating how cash conversion cycle affects the profitability. Results showed that average receivables period is having significantly positive association with profitability indicating that it is not necessary that always the moral of the story must be: lesser the cash conversion cycle, greater the profitability. The study takes Ebitda on net sales as measures of profitability to represent dependent variables.
\end{abstract}

Keywords: liquidity of assets, cash conversion cycle, profitability, firm structure

\section{Introduction}

This study was conducted with the aim to look into the association of the cash conversion cycle with the profitability of the firm.

Finding out some structural differences that lead towards statistically significant consequences, talking both of corporate profitability and of level of indebtedness, it is simpler to get a magic key to refine on business efficiency and corporate solvency. In other words, once you achieve the structure of assets which in three-year-period supervises firms to a higher profitability it is accordingly possible to lay the same foundations elsewhere, in other contests as well as in other firms for the achievement of the same positive results.

The aim of studying the issue of cash conversion cycle and its calculation, in this case, is focused on the discovery of the effects involving the profitability and the corporate leverage: which are larger between the two? The positive effects associating a higher monetary cycle to higher revenues and profitability? The negative effects involving a longer conversion cycle at more expensive costs and risks? To reply to this question this work aims to seek the existence of a relationship between asset composition and the debt capacity in one firm and in which terms the liquidability of assets affect the profitability of the firms over time.

The cash conversion cycle has been considered an important extent of firm's effective working capital management and particularly the cash management. Furthermore, the cash conversion cycle, actually, is the most significant part in working capital management. On the other side, working capital management is essential dynamic for a firm. There are direct and indirect effects on a firm's profitability and risk, and consequently its value.

It measures the time it takes to convert cash into cash again from the time when inventory is bought till the time inventory is sold and the bills are recovered (Padachi, 2006). Therefore the cash conversion cycle points out how the firms are performing and supports, thus, managers to understand the capacities where the company has room for improvement (Muscettola, 2014). This capital is the investment in current assets and current liabilities and is very decisive for a firm's survival. Given the above circumstances coupled with the fact that other sources of financing the firm are scarce, it has become imperative therefore for businesses to efficiently manage their working capital in order to become profitable (Muscettola, 2013).

Firms can exploit their value by having an optimal level of cash conversion period. Large inventory and generous trade credit policy stimulate sales and reduce the risk of stock-outs. On the other side trade credit and inventories are money locked up in working capital. Long time period to conversion the trade receivables or inventories can be expensive if a firm is not adequately capitalized, since they must be supplied by a quite 
number of external sources. This is also the situation with large accounts and extended trade credit, which can lead to cash inflow difficulties for the firm.

The most of the empirical studies that overflow in cash conversion cycle or in liquidity of assets, in the manufacturing industry, are drawn from developed markets while there are no similar studies with regard to the Italian territory. This paper, actually, attempts to fill this gap and contribute to the existing literature by using powerful instruments, like cluster analysis and ordinal logistic regression, to explore how profitable manufacturing firms-covering the period from 2007 to 2010-manage their cash conversion cycle and, vice versa, how the liquidity of assets influences their profitability. This study explores the relationship of accounts payable management, accounts receivables management, inventory management and cash to cash cycle management with profitability management in a sample of Italian SMEs. The conclusions of the study may direct managers of Italian manufacturing firms, and from other similar economies, to understand how cash conversion cycle impacts their profitability, which may augment their financial decision making.

The paper is organized into six sections. The research issues and literature review will be covered in next section. Section 3 considers the descriptive analysis and conceptual definitions. Section 4 presents and discusses the data in cluster analysis. In section 5 are introduced the empirical results and findings. Section 6 concludes the paper summarizing the results achieved.

\section{Library Review}

Among the preliminary studies on the matter, Richards and Laughlin (1980) portrayed the idea of cash conversion cycle as an instrument for determining the liquidity management and performance of a firm.

Shin and Soenen (1998), then, found significant effects from efficient cash cycle conversion management on profitability and liquidity of firms. Since that time many studies have taken place on the subject: link between the working capital and the profitability of firms, which conspicuous studies converge to similar results.

The link between the cash conversion cycle (or working capital management) and the returns has been studied by Deloof (2003) that, with the aid of a large sample of Belgian firms, demonstrated the aforementioned thesis of the direct consequence on the profitability of the average time of collection of trade receivables or of the average stock in the warehouse of products (Note 1).

Gosh and Maji (2003), on the same year, added positive consequences in terms of business efficiency about Indian firms. They endure the management of working capital.

Eljelly (2004) focused his own work looking for the relationship between the profitability and the asset liquidity using a sample of 929 firms in Saudi Arabia. In this case he detected a phenomenon of inverse proportionality between the liquidity of the corporate assets level and the corporate economy.

Lazaridis and Tryfondis (2006) proved the interrelation between the management of working capital of Greek firms and their profitability in such way to give to the efficiency of the cash conversion cycle a good mean for firms to search the optimal corporate economic structure (Note 2).

Padachi (2006) found that if the firm is invested higher in the inventories then the optimum level will diminish and profit will go down. Hutchison et al. (2007) observed significant association of cash conversion cycle with the return on investments of the companies. They suggested an inverse relationship between profitability and cash conversion cycle.

Rahemn and Nasr (2007) studied the impacts of the different turnover ratios (account receivables turnover, trade payables turnover and inventory turnover) on the performances of 94 quoted Pakistani firms. They also proved a negative and significant relationship between the width of the cash conversion cycle and the corporate profitability.

To them are to be added also Turuel and Solano (2007), whose study proved the same results on a large sample of Spanish SMEs (8.872). They suggested that firms should delay in making the payments for efficient performance.

Koumanakos (2008) stated that the higher the average inventories are sealed the lower the rate of return.

Samiloglu and Demirgunes (2008) analyzed the effect of working capital management practices on firms' profitability. They found a negative relationship between the profitability and the payables conversion period, the inventories conversion period and the financial leverage.

Also in other subsequent studies, it looks like less controversial, by the way, the link between the cash conversion cycle and the profitability of firms on which conspicuous studies converge to similar results. In 
chronological order, Afza and Nazir (2009), for a sample of 204 non-financial firms listed on the Karachi Stock Exchange (KSE), using regression analysis technique and data from 1998-2005, they find a significantly negative association between profitability and liquidity.

Falope and Ajilore (2009), for a sample of 50 quoted non-financial Nigerian firms, using panel data methodology and data from 1996-2005, they find the same results. Mathuva (2009), for a sample of 30 Kenyan listed firms, using panel data methodology and data covering the period from 1993-2008, finds a significantly negative relationship between accounts collection days and profitability, a significantly positive association between inventory conversion period and profitability and a significantly positive relationship between average payment days and profitability.

Luo et al. (2009) confirmed that if the value of the firm enhances the cash conversion cycle will decline.

Uyar (2009) also found significant association and linkage of working capital management with liquidity and profitability. He establishes that the size of a firm is negatively correlated to cash conversion cycle and a negative moving linkage of cash conversion cycle with firm's earnings was remarked.

Chatterjee (2010), for a sample of listed firms on the London Stock Exchange, employing the Pearson correlation data analysis technique, confirms a significantly negative association between profitability and liquidity and also significantly negative relationship between total debt and profitability.

Similarly, Dong and Su (2010), for a sample of listed Vietnamese firms, prove a significantly negative relationship between gross operating profit on one hand and the inventories conversion period and receivable conversion days on the other hand. Karaduman et al. (2010), for a sample of 140 firms listed on the Istanbul Stock Exchange, demonstrate a statistically significant negative association between return on assets on one hand and accounts receivable and inventory days on the other hand. The study further reveals a significantly positive relationship between accounts payable days and firm profitability.

Gill et al. (2010), for a sample of 88 US firms listed on the New York Stock Exchange, using data from 2005-2007, find no statistically significant relationship between average payable days and profitability and also between average inventory days and firm profitability. Similarly, they also observe no significant relationship between firm size and profitability but notice a negative association between accounts receivable and profitability. Ebaid (2011) confirms that the current cash flows have significant and direct impact to develop the profitability of the firms.

\section{Descriptive Analysis}

\subsection{Data Set}

The sample consists of Italian manufacturing SMEs, with revenues from 5 million to 50 million euro, during the period 2007 to 2010. In addition, we exclude firms that belong to financial and utility industries, as well as multi-segment firms that contain segments in the financial or service industries. The final sample consists of 16,904 firm-year observations (Note 3) that span 4,226 individual companies. Descriptive statistics for the sample are reported in Table 1 and in Table 2.

As follows, on Table 1, there is a description of fundamental parameters for the sample used in the survey:

Table 1. Characteristics of the sample used in the research: 4,226 Italian SMEs

\begin{tabular}{|c|c|c|c|c|c|c|}
\hline & \multicolumn{2}{|c|}{ Whole Sample } & \multicolumn{2}{|c|}{ Bad Firms } & \multicolumn{2}{|c|}{ Good Firms } \\
\hline & NR & $\%$ & NR & $\%$ & NR & $\%$ \\
\hline Manufacturing Firms & 4,226 & 100,00 & 257 & 6.08 & 3,969 & 93.92 \\
\hline \multicolumn{7}{|c|}{ Structural parameters } \\
\hline Sales (x 1,000€) & 15,255 & & 16,766 & & 15,160 & \\
\hline Total Assets (x 1,000 €) & 13,575 & & 20,263 & & 13,151 & \\
\hline Net Worth ( x $1,000 €$ ) & 3,868 & & 4,744 & & 3,813 & \\
\hline $\operatorname{EBITDA}(\mathrm{x} 1,000 €)$ & 1,330 & & 1,296 & & 1,333 & \\
\hline Cash Flow $(\mathrm{x} 1,000 €)$ & 802 & & 487 & & 822 & \\
\hline
\end{tabular}

The variables don't show considerable cross-sectional disparity, which suggests that the sample doesn't include a broad range of firms including, therefore, only specific firms-similar to themselves-inside a given macro-area. The choice in the selection of firms springs up from the preference to obtain a sample homogeneous enough in 
size (Note 4), location and category of firm (Muscettola \& Naccarato, 2013). That selection allows us, furthermore, to extend to the mass some attitudes, to standardize or normalize some data (Note 5) and, mostly, to better manage the outliers from the examined sample (Muscettola \& Pietrovito, 2012a).

In order to check relationship between the studied variables, descriptive analysis is used after adjusting for heteroskedasticity of data to mitigate the influence of extreme values (outliers). The continuous variables are winsorized at the $1 \%$ and $99 \%$ levels (Muscettola \& Gallo, 2008) and the missing values are swapped by averages relating to percentile of reference by a scheduled table (winsorization method).

\subsection{Explanatory Variables and Dependent Variable}

The explanatory variables taken in account in the present essay are four and concern the cash conversion cycle and its factorization. The dependent variable, conversely, detects the profitability of the firms. In such way it is possible to study the effects of the asset liquidity on returns of firms of the analysis sample. As follows the ten variables to which, for the purpose of testing the correct trend of the indicators, must be added four more control variables: "Total fixed assets / Total assets", "Cash and bank deposits / Total assets", "Inventory / Total assets" and "Trade receivables / Total assets".

Dependent variable:

1) Ebitda/Net sales: Earnings before Interest, Taxes, Depreciation and Amortization / Net sales (total revenues); Explanatory variables:

2) No. of days accounts receivable: Account receivable/Sales x 365;

In accountancy, days sales outstanding is a calculation used by a firm to estimate their average collection period and it measures the number of days on average that customers take to pay invoices. It is an index of the relationship between trade receivables and net sales achieved over one year. A higher ratio can specify a customer base with credit problems or a firm that is lacking in its collections activity (Note 6) A low ratio, on the other hand, may designate the firm's credit policy is too rigorous, which may be hindering sales.

3) No. of days inventories: Inventories/Cost of sales $x$ 365;

Days in inventory is a financial ratio that measures the average number of days the firm holds its inventory before selling it. The numerator of index is the average of inventory levels at the beginning and end of an accounting period.

4) No. of days account payable: Accounts payables/Purchases x 365;

Days payable outstanding measures the average number of days a firm takes to pay its suppliers and it provides one measure of how long a business holds onto its cash. Having a greater payables conversion period may indicate the firm's aptitude to delay payment and preserve cash. This could arise from better terms with vendors.

5) Cash conversion cycle: No. of days account receivable + No. of day inventories - No. days account payable;

In management accounting, the cash conversion cycle measures how long a firm will be deprived of cash if it increases its investment in capital in order to expand the sales. A firm could even realize a negative cash conversion cycle by collecting from customers before paying suppliers.

Control variables:

1) Total fixed assets/Total assets: Property, plant, equipment, long-term investments, credits with built-in over a year(Note 7) and intangible long-term assets / Total Assets;

2) Cash and bank deposits/Total assets: Immediate liquidity/Total Assets;

Inventory/Total assets: The raw materials, work-in-process goods and completely finished goods / Total Assets;

3) Trade receivables/Total assets: Total trade receivables/Total Assets;

The descriptive analysis shown in Table 2 describes the mean values of the variables. Ebitda on Sales is around 11.3 percent with standard deviation of 0.069 . The mean value for cash conversion cycle of all the firms together is around 79 days which is positive and a high standard deviation. This means that the companies pay their suppliers before it receives payment from the customers and consequently, they have a necessity to hold very much inventory. It means that the firms are selling the inventories (90 days) and are collecting receivables (150 days) later they have to pay their payables (212 days). 
Table 2. Summary statistics relative to 4,226 Italian manufacturing firms, with revenues from 5 million to 50 million euro, during the year 2007

\begin{tabular}{llllll}
\hline & Quartile 1 & Median & Mean & Quartile 3 & $\begin{array}{l}\text { Standard } \\
\text { Deviation }\end{array}$ \\
\hline No. of Days Accounts Receivable & 86.104 & 118.065 & 149.050 & 121.047 & 57.035 \\
No. of Days Inventories & 28.549 & 52.710 & 90.570 & 68.500 & 59.450 \\
No. of Days Account Payable & 113.669 & 157.882 & 212.174 & 177.444 & 107.762 \\
Cash Conversion Cycle & -40.107 & 20.091 & 79.354 & 12.252 & 124.029 \\
Total fixed assets/Total assets & 12.487 & 23.207 & 35.743 & 25.661 & 16.668 \\
Cash and bank deposits/Total assets & 0.520 & 2.856 & 9.669 & 7.256 & 10.455 \\
Inventory/Total assets & 10.397 & 19.006 & 29.019 & 20.823 & 13.683 \\
Trade receivables/Total assets & 28.048 & 39.311 & 51.462 & 40.137 & 17.382 \\
Ebitda/Sales & 4.790 & 7.405 & 11.342 & 8.721 & 6.870 \\
\hline
\end{tabular}

Correlation matrix (Table 3) is used to find the relationship between different variables used in the research. From the table it is clear how the most of variables it is not strongly self-related. Excluding those indicators composed from the same accounting items, like, id est, "No. of days inventories" and "Inventories / Total assets", the best correlations (positively related) to point out are between the cash and bank deposit and Ebitda. It is also quite intuitive the inverse relationship between cash and bank deposit and financial debts.

Table 3. Pearson correlation table for the variables that will be included in regression model

\begin{tabular}{|c|c|c|c|c|c|c|c|c|}
\hline & $\begin{array}{l}\text { No. of Days } \\
\text { Inventories }\end{array}$ & $\begin{array}{c}\text { No. of } \\
\text { Days } \\
\text { Account } \\
\text { Payable }\end{array}$ & $\begin{array}{c}\text { Cash } \\
\text { Conversion } \\
\text { Cycle }\end{array}$ & $\begin{array}{c}\text { Total } \\
\text { fixed } \\
\text { assets / } \\
\text { Total } \\
\text { assets }\end{array}$ & $\begin{array}{c}\text { Cash and } \\
\text { bank / Total } \\
\text { assets }\end{array}$ & $\begin{array}{c}\text { Inventory } \\
/ \\
\text { Total } \\
\text { assets }\end{array}$ & $\begin{array}{c}\text { Trade } \\
\text { receivables } \\
\text { / Total } \\
\text { assets }\end{array}$ & $\begin{array}{c}\text { Ebitda / } \\
\text { Sales }\end{array}$ \\
\hline No of Days Accounts Receiv. & 0.021 & 0.269 & 0.234 & -0.164 & -0.189 & -0.211 & 0.578 & 0.046 \\
\hline No. of Days Inventories & & -0.026 & 0.509 & -0.102 & -0.194 & 0.819 & -0.382 & -0.056 \\
\hline No. of Days Account Payable & & & -0.752 & 0.074 & 0.064 & -0.181 & 0.030 & 0.139 \\
\hline Cash Conversion Cycle & & & & -0.187 & -0.234 & 0.450 & 0.055 & -0.126 \\
\hline Total fixed assets/Total assets & & & & & -0.231 & -0.327 & -0.522 & 0.162 \\
\hline Cash and bank/Total assets & & & & & & -0.213 & -0.187 & 0.210 \\
\hline Inventory/ Total assets & & & & & & & -0.295 & -0.174 \\
\hline Trade receivables/ Total assets & & & & & & & & -0.163 \\
\hline
\end{tabular}

The correlation matrix table reveals also that there is positive and moderate correlation between No of Days Accounts Receivable and profitability. Similarly negative and weak correlation of stock turnover days was observed with profitability. Ultimately there is a negative and significant correlation between cash conversion cycle and profitability. For what may concern the control variables it is to underline the strong positive interrelation between inventories and "cash conversion cycle" and negative between "cash conversion cycle" and "no. of days account payable".

The profitability of firms takes advantage of positive links with the trade receivables conversion period, albeit very eager, with the debtors' turnover days, with the instant cash, and with fixed assets. The link turns negative, instead, with the inventory conversion period and with the incidence of stock on total assets, with the sum of the trade receivables to total assets and with the amplitude of the monetary cycle.

The other correlations are slender and negligible.

Among the arguable data just one stands out: the link between the profitability and the rigidity of assets that, in other terms, compels firms with less liquid assets and more borrowings to look for an output with a higher marginality to meet higher production costs, running costs and financial expenses. One further cause for a deepening is the positive ratio, very low yet, between the trade receivables conversion period and the profitability, as if this device of greater trade extension were a mean to get better prices (Note 8). On the other hand, there is a deeper negative link between the ilk profitability and the "Trade receivables/Total assets". This time the logical explanation is an indirect feature of the issue, due to the account receivables too often associated 
to a higher grade of leverage and to less cash, with all that may derive in terms of onerousness of debts, insofar they are burdened by higher credits.

\section{Cluster Analysis}

Here are shown some graphs portraying the cluster analysis (Note 9). In this way it is possible to combine the statistical units inserted into the sample, so as to minimize the "logical distance" within each group of firms and to maximize between groups.

Once the sample analysis have been parted in twelve clusters considering the distribution of the dependent variables (Profitability $=$ Ebitda/Net sales), let us see the trend of the means of the independent variables and the control variables (Muscettola \& Pietrovito, 2012b).

Figure 1 shows the relationship between the cash conversion period and the corporate profitability. Whereas the payables conversion period seems to share a good positive relationship of proportionality with the profitability, it is anyhow harder such interpretation in the other ratios. Firms accounting a strong profitability of sales, set inside clusters 10,11 and 12, absolutely enjoy a longer payables conversion period as well as a lesser overall cash conversion cycle (monetary cycle). All the rest looks very opaque.

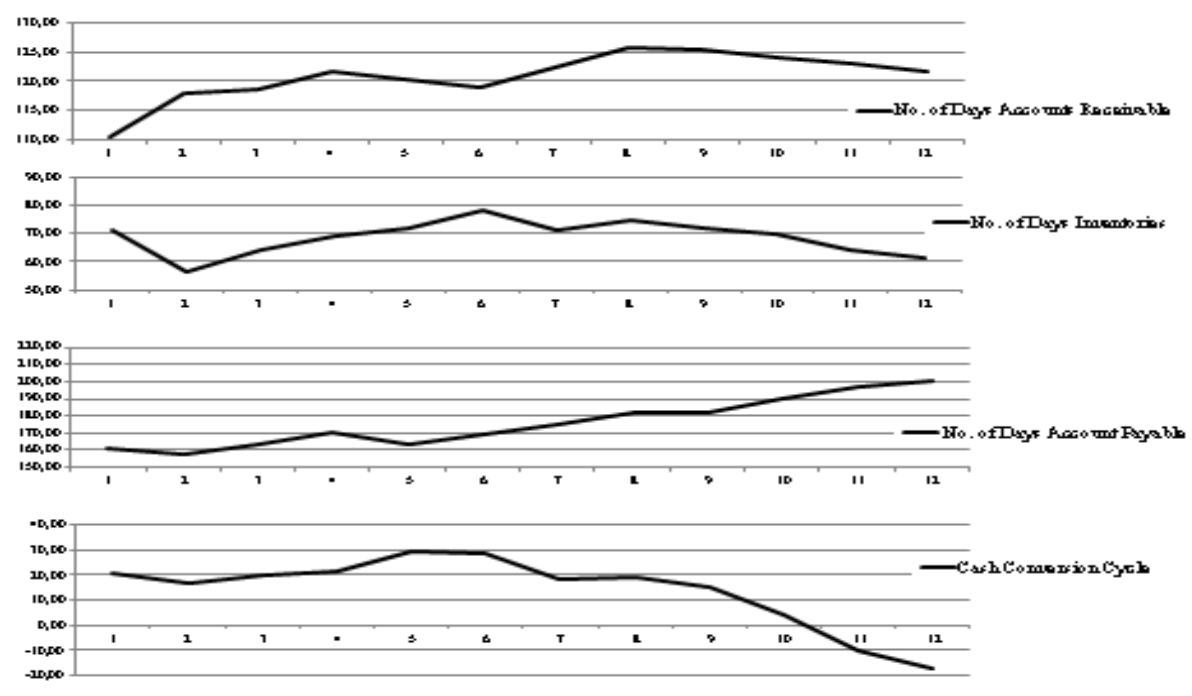

Figure 1. Distribution of cash conversion cycle, and its calculation, in view of corporate profitability in our sample of analysis

In Figure 2 there are the relationships between the trends of the averages of the ratios of composition of assets and the aforementioned corporate profitability ratio. In these situations, graphs describe clearer what is there in common among variables though, especially in central clusters, the trend analysis is not plain at all. Firms with a higher profitability have statistically produced an asset structure more rigid, more fixed assets, less trade receivables and less inventories. The ratio formed between the fixed assets and the total assets gives rise to an increasing trend going on quite linearly with the exclusion of firms inserted into the lowest profitability cluster. Similarly, but in the opposite sense, the impact of trade receivables on total assets keep a plain trend though decreasing as the profitability rises. The indicator trend representing the instant liquidity remains fairly flat until the last three bigger classes of profitability. Watching it from the opposite side, it is quite trivial to picture firms with a strong profitability as companies able to store higher liquid resources. The percentage of stocks on total assets shows a flat trend until the sixth cluster that afterwards gets down constantly and linearly as the corporate profitability grows up. 

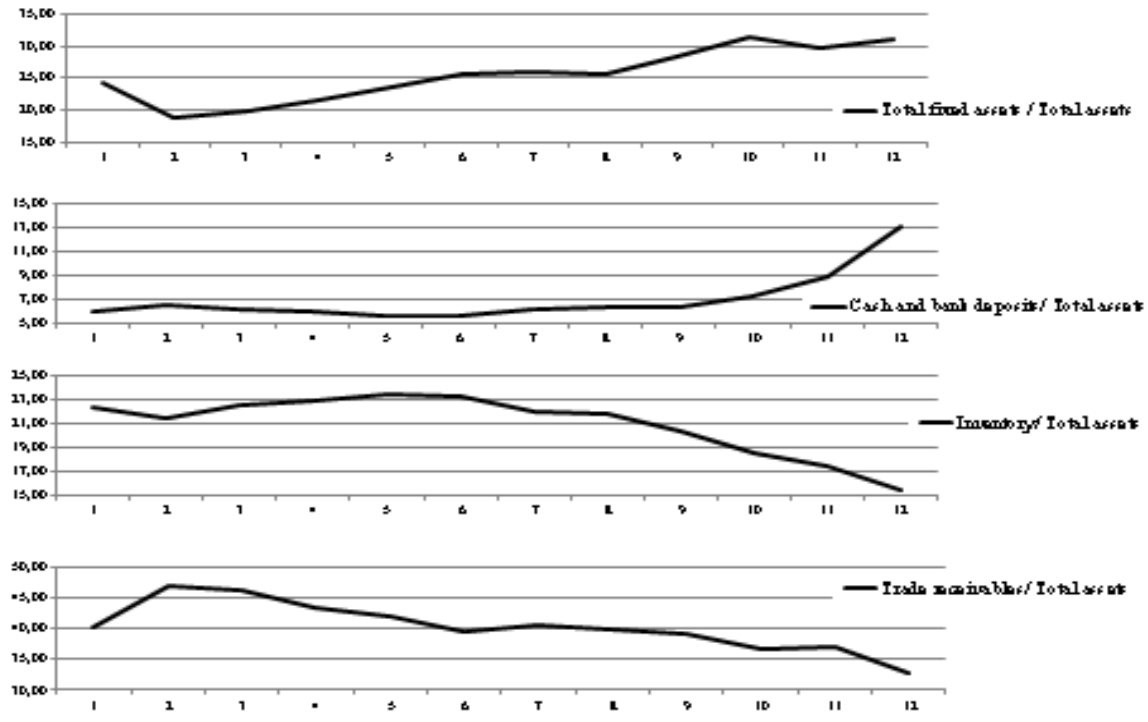

Figure 2. Distribution of composition of assets in view of corporate profitability in our sample of analysis

\section{Empirical Analysis}

To examine the association an ordinal regression analysis (Note 10) has been performed on the level of dependent variable on the explanatory variables. Has been also taken into account the set of control variables? as mentioned, that have not been shown to intensely correlate with dependent variables. The regression analysis finds out the effect and relationship of explanatory variables with profitability of firms. Ebitda on net sales, therefore, is regressed with independent and control variables to get the products of the predicted relationships.

The dependent variable has been subdivided into ten ordinal clusters considering the decile reference to the distribution, starting from minimum to maximum value: any one of values dividing the distribution of the dependent variables in the series into ten groups of equal frequency (Note 11).

An use of indicators already marked as predictor variables will be proposed in ordinal logistic regression to find the parameter estimates. Statistical significance is estimated using standard errors that are grouped at the firm level and are robust to heteroskedasticity and autocorrelation. Each logit has its own term but the same coefficient. That means that the effect of the independent variable is the same for different logit functions (Note 12). In such sense, in spite of the binary logistic regression model, that is not linear, it is possible to interpret the sign and the statistical significance of the coefficients but not the size.

As illustrated on Table 4, the terms, called the "threshold" values, do not depend on the values of the independent variable. They are like the intercept in a linear regression, except that each logit has its own. The estimates tagged as "location" are the coefficients for the predictor variables. The "Wald" statistic is the square of the ratio of the coefficient to its standard error.

Results of ordinal regression analysis with profitability are shown in Table 3 below.

The ordinal regression results show that the cash conversion cycle is significantly and positively related to Ebitda which reverses the common rule of lesser the cash conversion cycle greater would be the profitability of firms. It specifies that higher the cash conversion cycle greater would be the profitability as measured by Ebitda on net sales.

It is not statistically expressive the coefficient associated to the number of Days Inventories, as already seen on previous descriptive analysis. Also positive are the coefficients of "cash and bank deposit" and, though less statistically significant, "total fixed assets". On the other side, the coefficients of "Inventory/Total assets" and "Trade receivables/Total assets" stand negative, as already posted on previous analysis.

Positive is the relationship between profitability and number of days receivables. These findings imply that decreasing firms' receivable days lead to a declining profit while significant financial success can be attained with increased payable days. This suggests also that managers can enhance the profitability of their firms by raising the number of days for their account receivables. 
Table 4. Ordinal logistic regression

\begin{tabular}{|c|c|c|c|c|c|c|c|c|}
\hline \multirow{2}{*}{\multicolumn{2}{|c|}{ PROFITABILITY }} & \multirow{2}{*}{ Sign } & \multirow{2}{*}{ Estimate } & \multirow{2}{*}{ Std. Error } & \multirow{2}{*}{ Wald } & \multirow{2}{*}{ P-Value } & \multicolumn{2}{|c|}{$95 \%$ Confidence Interval } \\
\hline & & & & & & & Lower Bound & Upper Bound \\
\hline \multirow{9}{*}{ Threshold } & {$[$ profitability $=1]$} & & -2.575 & 0.300 & 73.478 & 0.000 & -3.164 & -1.986 \\
\hline & [profitability $=2]$ & & -1.720 & 0.298 & 33.273 & 0.000 & -2.305 & -1.136 \\
\hline & [profitability $=3$ ] & & -1.131 & 0.297 & 14.477 & 0.000 & -1.714 & -0.549 \\
\hline & {$[$ profitability $=4]$} & & -0.640 & 0.297 & 4.649 & 0.031 & -1.222 & -0.058 \\
\hline & [profitability $=5]$ & & -0.186 & 0.297 & 0.391 & 0.532 & -0.767 & 0.396 \\
\hline & [profitability $=6$ ] & & 0.271 & 0.297 & 0.836 & 0.361 & -0.310 & 0.853 \\
\hline & [profitability $=7]$ & & 0.771 & 0.297 & 6.734 & 0.009 & 0.189 & 1.353 \\
\hline & [profitability $=8]$ & & 1.374 & 0.298 & 21.292 & 0.000 & 0.790 & 1.957 \\
\hline & [profitability $=9]$ & & 2.265 & 0,300 & 57.020 & 0.000 & 1.677 & 2.853 \\
\hline \multirow{9}{*}{ Location } & No. of Days Accounts Receivable & + & 0.003 & 0.001 & 6.704 & 0.010 & 0.001 & 0.006 \\
\hline & No. of Days Inventories & - & -0.002 & 0.001 & 1.540 & 0.215 & -0.005 & 0.001 \\
\hline & No. of Days Account Payable & + & 0.005 & 0.001 & 19.389 & 0.000 & 0.003 & 0.007 \\
\hline & Cash Conversion Cycle & + & 0.004 & 0.001 & 12.799 & 0.000 & 0.002 & 0.006 \\
\hline & Total fixed assets / Total assets & + & 0.011 & 0.003 & 10.623 & 0.001 & 0.004 & 0.018 \\
\hline & Cash and bank / Total assets & + & 0.028 & 0.004 & 49.574 & 0.000 & 0.020 & 0.036 \\
\hline & Inventory/ Total assets & - & -0.027 & 0.005 & 29.232 & 0.000 & -0.037 & -0.017 \\
\hline & Trade receivables/ Total assets & - & -0.032 & 0.004 & 76.004 & 0.000 & -0.039 & -0.025 \\
\hline & Pseudo R-squared & 0.035 & & & & & & \\
\hline
\end{tabular}

Pseudo R-squared has been adopted as improvement from null model to fitted model and as a goodness-of-fit measure. McFadden's approach (Note 13) use occurred, too. The denominator of the ratio is the sum of squared errors from the null model (Note 14).

The ratio of the likelihoods suggests the level of improvement over the intercept model offered by the full model. The results of $\log$ likelihoods indicate that the full model is a far better fit than the intercept model (Pseudo R-squared $=0.035$ ).

\section{Conclusions}

Generally cash management is based on cash conversion cycle and is considered as important factors enhancing the performance of companies (Muscettola, 2010), since it shows how efficient a firm is in its payments of bills, collection of payments, and selling of inventory. The cash cycle is a very powerful tool for examining how well a manufacturing company's working capital is being managed. Financial managers have to run the manufacturing companies for longer period and for that they make decisions to manage working capital by creating a balance between the available current assets and current liabilities.

Previous research predicts negative relationship between trade receivables conversion period and corporate profitability. In this research the results are not in line with these outcomes. The positive relationship between accounts receivables and firm's profitability, in fact, suggest that the trade credit can be used as a strategic tool to improve the profitability. It seems that operational profitability dictates how managers act in terms of managing accounts receivables. Thus, the conclusions of this paper suggest that managers can create value by raising the number of days for accounts receivables, although this leads to an increase of their cash gap in the cash conversion cycle. On the basis of findings of this paper, it is possible to conclude that the profitability can be enhanced if firms manage their working capital in a less efficient way.

Just like what found out by the research of Gill et al. (2010), this study reveals also no significant connection, within the sample of manufacturing firms, regarding the relationship between the average number of days the inventory is held and the firm's earnings. 
As regards the payables conversion period in this research is proved that lower gross operating profit is associated with a decrease in the debtors' turnover days, in contrast with previous studies that reported negative correlation. Just in order to counterbalance the aspect mentioned above, more profitable firms wait longer to pay their bills taking advantage of credit period granted by their suppliers. This suggests that less firm's earnings will follow a decline of their trade credits in an attempt to cut their cash gap in the cash conversion cycle.

It is not well defined, finally, the relationship between aggregate cash conversion cycle and corporate profitability. This paper verified a positive relationship in an ordinal logit regression, a negative Pearson's correlation and a negative trend but not perfectly readable as regards the cluster analysis with a not significant curvilinear line with increasing the corporate profitability. The findings showed, therefore, that cash conversion cycle is not having significantly association with profitability indicating that it is not necessary that always there must be lesser the cash conversion cycle greater would be the profitability. If the firm is able to sell the inventory and collect the receivables it is all you need to get a good efficiency and corporate solvency.

As regards the control variables, the rigidity of the assets has a positive relationship, statistically significant, with the profitability. Reverse the incidence of inventories and trade receivables to total assets have showed a negative trend.

The analysis linking corporate assets to profitability has further repercussions, the empirical study of which is beyond the scope of this paper. We show that the relation between asset liquidity and profitability depends strongly on investment opportunities and, least as far as the sample of Italian firms analysed, cannot be easily generalized.

\section{References}

Afza, T., \& Nazir, M. S. (2009). Impact of Aggressive Working Capital Management Policy on Firm's Profitability. The IUP J. Appl. Financ., 19-30. http://dx.doi.org/10.5897/JEIF2013.0539

Altman, E. I., \& Sabato, G. (2007). Modelling credit risk for SMEs: evidence from the U.S. market. Abacus, 43, 332-357. http://dx.doi.org/10.1111/j.1467-6281.2007.00234.x

Chatterjee, S. (2010). The Impact of Working Capital Management on the Profitability of the Listed Companies on the London Stock Exchange. Working Paper Series.

Deloof, M. (2003). Does working capital management affect profitability of Belgian firms? Journal of Business, Finance \& Accounting, 30, 573-587. http://dx.doi.org/10.1111/1468-5957.00008

Dong, H. P., \& Su, J. (2010). The Relationship between Working Capital Management and Profitability: A Vietnam Case. Int. Res. J. Financ. Econ, 49, 59-67.

Ebaid, I. E. (2011). Accruals and the prediction of future cash flows: Empirical evidence from an emerging market. Management Research Review, 34(7), 838-853. http://dx.doi.org/10.1108/01409171111146715

Eljelly, A. (2004). Liquidity-profitability trade-off: an empirical investigation in an emerging market. International Journal of Commerce and Management, 14, 48-61. http://dx.doi.org/10.1108/10569210480000179

Enqvist, J., Graham, M., \& Nikkinen, J. (2008). The impact of working capital management on firms profitability in different business cycles: Evidence from Finland. Retrieved from http://ssrn.com/abstract=1794802

Falope, O. I., \& Ajilore, O. T. (2009). Working Capital Management and Corporate Profitability: Evidence from Panel Data Analysis of Selected Quoted Companies in Nigeria. Res. J. Bus. Manage, 3, 73-84.

Gai, L. (2008). Il rating delle PMI. Un approccio metodologico per banche, confidi e intermediari finanziari. FrancoAngeli Editore

Gill, A., Biger, N., \& Mathur, N. (2010). The Relationship Between Working Capital Management And Profitability: Evidence From The United States. Business and Economics Journal.

Ghosh, S. K., \& Maji, S. G. (2003). Working capital management efficiency: a study on the Indian cement industry. The Institute of Cost and Works Accountants of India.

Hutchinson, D. E., \& Cox, R. A. K. (2007). The casual relationship between bank capital and profitability. Annals of Financial Economics.

Karaduman, H. A., Akbas, H. E., Ozsozgun, A., \& Durer, S. (2010). Effects of Working Capital management on Profitability: The Case of Selected Companies in the Istanbul Stock Exchange (2005-2008). Int. J. Econ. 
Financ. Stud, 2(2), 47-54.

Lazaridis, I., \& Tryfonidis, D. (2006). Relationship between working capital management and profitability of listed companies in the Athens stock exchange. Journal of Financial Management and Analysis, 19, 25-26. Retrieved from http://papers.ssrn.com/sol3/papers.cfm?abstract_id=931591

Luo, M. M., Yee Lee, J. J., \& Hwang, Y. (2009). Cash Conversion Cycle, Firm Performance and Stock Value. Retrieved from http://www90.homepage.villanova.edu/michael.pagano/ML_CC C_20090420.pdf

Koumanakos, D. P. (2008). The effect of inventory management on firm performance. International Journal of $\begin{array}{llll}\text { Productivity and } \quad \text { Performance 335-369. } & \text { Manement, }\end{array}$ http://dx.doi.org/10.1108/17410400810881827

Mathuva, D. M. (2009). The Influence of Working Capital Management Components on Corporate Profitability: A Survey on Kenyan Listed Firms. Res. J. Bus. Manage, 3(1), 1-11.

Muscettola, M., \& Gallo, M. (2008). Analisi e gestione del rischio di credito. Il progetto Mayflower. Franco Angeli Editore.

Muscettola, M. (2010). Analisi di bilancio ai fini dell'accesso al credito. FrancoAngeli Editore.

Muscettola, M., \& Pietrovito, F. (2012a). Le caratteristiche delle imprese insolventi. Il Rating tra impresa, banca e territorio. Sinergie Editore.

Muscettola, M., \& Pietrovito, F. (2012b). La rilevanza delle variabili finanziarie nel rating: i risultati di un'analisi empirica sulle PMI italiane. Rapporti di ricerca. Nr., 36. Sinergie Editore.

Muscettola, M., \& Naccarato F. (2013). Probability of Default and Probability of Excellence, an Inverse Model of Rating. One More Tool to Overcome the Crisis: an Empirical Analysis. Selected papers of the 1st B.S.Lab International Symposium edited by Business System Review. http://dx.doi.org/10.7350/BSR.BV06.2013

Muscettola, M., \& Modina, M. (2013). The quality of a regional rating. An empirical evidence on Italian SMEs. Arethuse, 81-101.

Muscettola, M. (2013). Leverage Risk. The weight of borrower capital distinguishes the solvency of firms: an empirical analysis on a sample of 4,500 Italian SMEs. International Journal of Economics and Finance, 5(12). http://dx.doi.org/10.5539/ijef.v5n12p24

Muscettola, M. (2014). Structure of assets and capital structure. What are the relations with each other? An empirical analysis of a sample of Italy. European Journal of Business and Social Sciences, 2(11), 55-69.

Padachi, K. (2006). Trends in Working Capital Management and its Impact on Firms' Performance: An Analysis of Mauritian Small Manufacturing Firms. International Review of Business Research Papers, 2(2), $45-58$.

Raheman, A., \& Nasr, M. (2007). Working capital management and profitability - case of Pakistani firms. International Review of Business Research Papers, 3, 279-300.

Richards, V. D., \& Laughlin, E. J. (1980). A Cash Conversion Cycle Approach to Liquidity Analysis. Financial Management, 9(1), 32-38. http://dx.doi.org/10.2307/3665310

Samiloglu, F., \& Demirgunes, K. (2008). The effect of working capital management on firm profitability: Evidence from Turkey. Int. J. Appl. Econ. Finance, 2(1), 44-50. http://dx.doi.org/10.3923/ijaef.2008.44.50

Shin, H. H., \& Soenen, L. (1998). Efficiency of Working Capital and Corporate Profitability. Financial Practice and Education, 8(2), 37-45.

Teruel, P. J. G., \& Solano, P. M. (2007). Effects of working capital management on SME profitability. International journal of Managerial Finance, 3(2), 164-177.

Uyar, A. (2009). The Relationship of Cash Conversion Cycle with Firm Size and Profitability: An Empirical Investigation in Turkey. International Research Journal of Finance and Economics, 24.

\section{Notes}

Note 1. He stated that for better performance the time duration for collection of receivable should be kept short.

Note 2. Their results from regression analysis showed strong association between gross operating profit and CCC. 
Note 3. The yearly statements are provided by FourFinance Sas, which assembled, cleaned, regulated and reclassified financial statements collected from multiple databases as, above all, Cerved Group Spa and Crif Spa. As for the creation of the statistical model, the preliminary operations on the data, the choice of the outliers and the creation of financial ratios, the reader ought to refer exclusively to the authors.

Note 4. The conclusions reached by Altman e Sabato (2007) confirm the need to use a specific predictive model for SMEs rather than adopting tools built on generic samples.

Note 5. To obtain a working model, empirically verifiable all time long and transferable (in time and space), there is to use primarily clear and valid information sources and attainable data measurable in time (Gai, 2008). To that aim the distinction of the segments of the sample was simplified and the model was built with a non-excessive series of variables linkable to data ever large and achievable enough.

Note 6. It can result in cash flow problems.

Note 7. Any asset that the firm does not expect to sell for at least a year or not readily convertible to cash that is used in the normal course of business.

Note 8. It can result in cash flow problems.

Note 9. Cluster analysis is a multivariate analysis technique. Its task is to gather a set of objects in such a way that objects in the same group (called a cluster) are more similar (in some sense or another) to each other than to those in other groups (clusters).

Note 10. Ordered logistic regression is used when the dependent variable is ordered, but not continuous. For ordinal categorical variables it is possible to modify the binary logistic regression model to incorporate the ordinal nature of a dependent variable by defining the probabilities differently. Instead of considering the probability of an individual event, we consider the probability of that event and all events that are ordered before it.

Note 11. One of nine values (There are nine thresholds for this model because there are ten levels of the outcome variable) of a variable dividing its distribution into ten groups with equal frequencies: the ninth decile is the value below which $90 \%$ of the population lie.

Note 12. One of the assumptions underlying ordinal logistic (and ordinal probit) regression is that the relationship between each pair of outcome groups is the same. In other words, ordinal logistic regression assumes that the coefficients that describe the relationship between, say, the lowest versus all higher categories of the response variable are the same as those that describe the relationship between the next lowest category and all higher categories, etc. This is called the proportional odds assumption or the parallel regression assumption. Because the relationship between all pairs of groups is the same, there is only one set of coefficients (only one model).

Note 13. The smaller this ratio, the greater the improvement and the higher the R-squared. The log likelihood of the intercept model is treated as a total sum of squares, and the log likelihood of the full model is treated as the sum of squared errors.

Note 14. A model that predicts the dependent variable without any independent variables.

\section{Copyrights}

Copyright for this article is retained by the author(s), with first publication rights granted to the journal.

This is an open-access article distributed under the terms and conditions of the Creative Commons Attribution license (http://creativecommons.org/licenses/by/3.0/). 